\title{
Sequential extraction procedure as a tool to investigate PTHE geochemistry and potential geoavailability of dam sediments (Almadén mining district, Spain)
}

\author{
Efrén García-Ordiales ${ }^{\mathrm{a}, *}$, Stefano Covelli ${ }^{\mathrm{b}}$, José María Esbrí ${ }^{\mathrm{c}}$, Jorge Loredo ${ }^{\mathrm{a}}$, Pablo L. Higueras ${ }^{\mathrm{c}}$ \\ a Mining, Energy and Materials Engineering School, University of Oviedo, Oviedo, Spain \\ ${ }^{\mathrm{b}}$ Department of Mathematics and Geosciences, University of Trieste, Trieste, Italy \\ c IGEA, Biogeochemistry Laboratory of Heavy Metals, University of Castilla La Mancha, Almadén, Ciudad Real, Spain
}

\section{A R T I C L E I N F O}

\section{Article history:}

Received 30 October 2015

Received in revised form 23 July 2016

Accepted 25 July 2016

Available online $\mathrm{xxxx}$

\section{Keywords:}

Mining activity

Stream sediments

Artificial reservoir

Sequential extraction procedure

Ecological risk

\begin{abstract}
A B S T R A C T
Sediments from Castilseras reservoir (Almadén) were collected to assess the potential environmental hazards associated with the availability of Potentially Toxic or Harmful Elements (PTHE) in this freshwater environment. PTHE concentrations in sediments were investigated using a four step (F1-F4) Sequential Extraction Procedure (SEP) and the results were evaluated using Principal Component Analysis (PCA) and different risk indexes and criteria. Considering the fractions results and the PCA treatment, two groups of elements can be differentiated in the easily leached by weak acids fraction $\mathrm{F} 1$ and these indicate the presence of sulfate and secondary precipitates of carbonates as the main sink for easily accessible metallic elements. In reducible fraction F2, chemical analysis revealed a significant relationship between the majority of the analyzed elements and the Fe oxy-hydroxides, with the exception of $\mathrm{Co}, \mathrm{Hg}$ and $\mathrm{Ni}$, which are preferentially associated with $\mathrm{Mn}$ oxy-hydroxides. In the oxidizable fraction (F3), a significant relationship between $\mathrm{Cu}, \mathrm{Fe}, \mathrm{Hg}$ and $\mathrm{Zn}$ (representative metals of the existing ore deposits) and sulfides/organic matter was observed. The environmental assessment based on the aforementioned criteria provides risk levels varying from moderate to high. The risk appears to be higher near the dam, where the higher PTHE levels in sediment are due to a selective accumulation of fine-grained particles.
\end{abstract}

(c) 2016 Elsevier B.V. All rights reserved.

\section{Introduction}

Trace metals and metalloids are usually found at background levels in fluviatile sediments, including water reservoirs, except where anthropogenic activities lead to an increase in their concentrations due to air-borne, terrigenous and aqueous inputs (Dhanakumar et al., 2015; Wang et al., 2015). Some of these metals are referred to as "Potentially Toxic or Harmful Elements" (PTHE) (EU, 2001). In particular, mining activities can adversely affect the quality of the fluvial environment by introducing these PTHE in association with particles or in solution. PTHE supply and concentration are highly variable over space and time in the watershed hosting active or dismissed mining areas, and they depend on the characteristics and significance of mine wastes and metal sources as well as the underlying geology, geochemistry and weathering of ore deposits. The amount of PTHE also varies in response to seasonal flow variability, including drought conditions. In particular, mine operations developed over long time periods in historical mining districts have had significant adverse environmental effects in proximity ecosystems (Gosar et al., 1997; Vrhovnik et al., 2013;

\footnotetext{
* Corresponding author.

E-mail address: garciaefren@uniovi.es (E. García-Ordiales).
}

Resongles et al., 2014). Evidence of contamination can frequently be found beyond the local mined area and in some cases significant contamination can be detected several tens of kilometers away from the source (Pettine et al., 1982; Gosar et al., 1997; Lechler et al., 1997; Gosar, 2008; Covelli et al., 2012; Bavec et al., 2014; Gray et al., 2014; Tornero et al., 2014).

Given the low solubility in water of most of these elements and their tendency to be adsorbed by fine suspended particles (Acosta et al., 2009; Duan et al., 2010), fluvial sediments are important to evaluate the quality of the riverine environment (Yuan et al., 2014). If they are present within the drainage basins, artificial water reservoirs can be considered as important barriers that significantly alter the natural hydrological flow and the transport of materials. These basins promote sedimentation processes and they become significant repositories of PTHE associated with sediments (Loska and Wiechuła, 2003; Rimondi et al., 2012). Moreover, the specific physico-chemical conditions found in these reservoirs when compared to flowing waters may induce the development of biologically mediated transformations of inorganic PTHE into different species that may be more toxic for the environment (Adriano, 2001). Therefore, sediments in the reservoir can be considered as a sink and/or source of contaminants and their ecological risk assessment should be a priority in order to assess the environmental quality of the fluvial compartment (Dević et al., 2016; Fang et al., 2016). 
As a result of previous studies on mining districts throughout the world, aquatic ecosystem contamination by PTHE has been recognized as one of the most important environmental issues related to the toxicity, abundance, persistence and bioaccumulative character of these compounds (Sin et al., 2001; Ruiz et al., 2008). Sediments downstream mining areas provide important information about the impact suffered by the aquatic ecosystems and help to determine the associated risk assessment (Varol, 2013).

In the work described here, the mobility of PTHE in the sediments of the Castilseras reservoir has been investigated by applying a Sequential Extraction Procedure (based on the BCR methodology). In this study several environmental quality indexes, from those available from literature, were applied. The results provide relevant information that enables appropriate strategies to be recommended when planning environmental management of this drainage basin.

\section{Study area}

The Castilseras reservoir is located in the central part of the Almadén $\mathrm{Hg}$ mining district (Ciudad Real, central Spain). It was constructed in 1983 and it has a surface area of $97 \mathrm{ha}$, a water capacity of $5 \mathrm{hm}^{3}$ and maximum depth of $14 \mathrm{~m}$. The district covers an area of $120 \mathrm{~km}^{2}$ and it was the largest producer of $\mathrm{Hg}$ at a world level for $>2000$ years (Hernández et al., 1999). From a geological point of view, the rocks that crop out in Almadén are mainly siliciclastic. $\mathrm{Hg}$ mineralizations are hosted by Paleozoic (meta)detritic rocks with a significant volume of interbedded magmatic rocks to form a tectonic structure, the Almadén syncline (Hernández et al., 1999). The Castilseras reservoir is built on Pre-Ordovician (meta)detritic rocks (shales and greywackes) that constitute the Alcudia anticline, located at the south of the Almadén syncline. The dam is located in the Valdeazogues watershed, which is the main river in the mining district. The extensive $\mathrm{Hg}$ mining and metallurgical activity developed over centuries, along with other minor mining activities involving $\mathrm{Pb}, \mathrm{Zn}$ and Ag recovery, has led to significant PTHE inputs in the different environmental compartments of the district (Gray et al., 2004; Molina et al., 2006; Higueras et al., 2006, 2011, 2012; Millán et al., 2006, 2012; Dago et al., 2014). The different inputs from the abandoned mining installations and spoil heaps have been producing adverse effects to ecosystems in proximity to the mining areas for long periods of time. However, the extent of contamination is not strictly limited to the vicinity of mines; contaminated material may be physically remobilized during floods, thus dispersing contaminants over hundreds of kilometers from historical mine sites. The environmental quality of the Valdeazogues River has been negatively affected by run-off waters from the mined areas (Berzas Nevado et al., 2003; García-Ordiales et al., 2014).

The hydrological conditions in the district are mainly determined by the seasonality of the Valdeazogues River, which is controlled by the semiarid climate of the area. The area suffers long periods of drought when the reservoir recharge may reach very low values (approximating zero), enhancing the lentic nature of this lake, and may undergo long periods of evaporation induced by high temperatures and solar radiation. The Castilseras reservoir is the only lentic medium located within the Almadén mining district. This reservoir collects rainwater, mine drainages and leachate from spoil heaps from four of the most important abandoned $\mathrm{Hg}$ mines of the district (Las Cuevas, El Entredicho, Nueva and Vieja Concepción, see Hernández et al., 1999 for details). A schematic view of the studied area is shown in Fig. 1 and this includes the main mercury and polymetallic mines and the location of the sediment sampling points in the reservoir.

\section{Materials and methods}

\subsection{Sample collection and chemical analysis}

A total number of 12 sampling stations (labelled Cs in Fig. 1) were considered along the main reservoir axis from the dam to the head of the reservoir. Bottom reservoir sediments were collected by means of a Van Veen grab and they were subsampled and homogenized on field, and stored in a refrigerator during transport to the laboratory.

Once in the laboratory, sediments were lyophilized (48 h). Dry samples were then sieved through a $2 \mathrm{~mm}$ mesh to discard the coarser fraction (gravel). The resulting $<2 \mathrm{~mm}$ fraction was subsequently homogenized and crushed in an agate mortar and in an agate ball mill to a size $<63 \mu \mathrm{m}$ mesh, and stored in a refrigerator prior to analysis.

The total $\mathrm{Hg}$ content in samples was determined by thermal decomposition followed by Atomic Absorption Spectrometry (AAS) coupled with gold amalgamation (LECO® AMA - 254 Model). Samples were analyzed in the solid state according to the methodology proposed by Costley et al. (2000). Quality control was tested using certified reference materials (CRM): PACS-2, CRM026-050 and CRM042-056. The recovery percentages (RP) for these materials were between $93 \%$ and $109 \%$, and the calculated relative standard deviations in \% (RSD) for three replicates of each material were $<10 \%$.

Major and PTHE were analyzed at Acme Analytical Laboratories Ltd. (Vancouver, Canada) by Inductively Coupled Plasma Atomic Emission Spectroscopy (ICP-AES) and Inductively Coupled Plasma Mass Spectrometry (ICP-MS) after digestion of $0.5 \mathrm{~g}$ of sample in hot aqua regia $\left(95^{\circ} \mathrm{C}\right)$. All elements were analyzed in batches, which included a procedural blank and a certificate reference material (CRM). Each calibration curve was evaluated by analyses of quality control standards before, during and after the analyses of a set of samples. The accuracy for elemental determination was controlled using CRM: STD OREAS45CA, STD DS8 and CRM042-056. RP of the different elements range from $82 \%$ to $111 \%$ and the RSD was $<7 \%$.

The sequential extraction procedure (SEP) applied was based on the BCR methodology (Quevauviller et al., 1997) adapted to a four-step scheme as reported, for instance, by Sahuquillo et al. (1999) and Delgado et al. (2011). Briefly, the different steps of the SEP allowed four fractions to be differentiated: the first fraction (F1), extracted by a solution of $0.11 \mathrm{M}$ acetic acid, that includes the species that are soluble in water, easily leached by weak acids and associated with soluble carbonates; the second fraction (F2), extracted by $0.1 \mathrm{M}$ hydroxylammonium chloride, consists of the easily reducible species, associated with Fe and Mn oxy-hydroxides; the third fraction (F3), extracted by $8.8 \mathrm{M}$ hydrogen peroxide $+1 \mathrm{M}$ Ammonium acetate, includes the easily oxidisable species, mainly associated with organic matter and sulfide minerals (Li and Thornton, 2001); and the fourth fraction (F4), extracted by aqua regia $+\mathrm{HF}$, contains those species extracted from silicates or sulfides, with low solubility.

The four fractions were analyzed at the General Research Services of Oviedo University on an ICP-MS by applying EPA method 200.8 (Brockhoff et al., 1999). Quality control was tested using nonspecific CRM: CRM042-056 and PACS-2. The recovery percentages (sum of recovery/total) were in the range between $91 \%$ and $106 \%$.

Principal Component Analysis (PCA), performed with Minitab and SPSS statistical software for MS Windows V15 and V17, respectively, were employed to process the SEP results.,

\subsection{Risk assessment}

Several indexes available in the relevant literature were applied in an effort to estimate the potential environmental risk based on the concentrations and availability of elements in a reservoir sediments (Liu et al., 2009; Michalec, 2012; Tang et al., 2014, among others). Each one of the selected indexes provides important information for a comprehensive risk assessment, comparing the detected values with local, legal and potential risk to the biota levels.

The degree of contamination index (Cd) (Håkanson, 1980; Abrahim, 2005; Yang et al., 2009), is a simple index that allows an assessment of the pollution level due to PTHE or organic pollutants in soils and 
sediments. Cd was calculated with the following equations:

$C f=\frac{C s_{i}}{C b_{i}}$

$C d=\frac{1}{n} \sum C f$

where $C s_{i}$ is the measured concentration of the examined metal $(i)$ in the soil sample; $C b_{i}$ is the background value of heavy metal $(i)$ in the uncontaminated soil (control); $C f$ is the contamination factor; and $(n)$ the number of element used for the calculation. In this case, control values from García-Ordiales et al. (2014) were selected.

The mean probable effect concentration quotient index (mPEC-Q), developed by MacDonald et al. (2000), is a measurement of the estimated chemical pollution level in sediments, in relation to established sediment quality guidelines. For the present study, the Threshold Effect
Levels (TELs) reported by the Screening Quick Reference Tables (SQRT), developed by the US National Oceanographic and Atmospheric Administration (NOAA) (Buchman, 2008), were selected to apply with this index due to these values set the threshold at which possible adverse effects occasionally occur. The MPEC-Q index was calculated according to the following equations:

$P E C-Q=\frac{\text { chemical concentration }(\text { dry wt. })}{\text { corresponding PEC value }}$

$m P E C-Q_{\text {metals }}=\frac{\sum \text { individual metal } P E C-Q_{s}}{n}$

where $n=$ number of classes of chemicals for which sediment chemistry data were available.
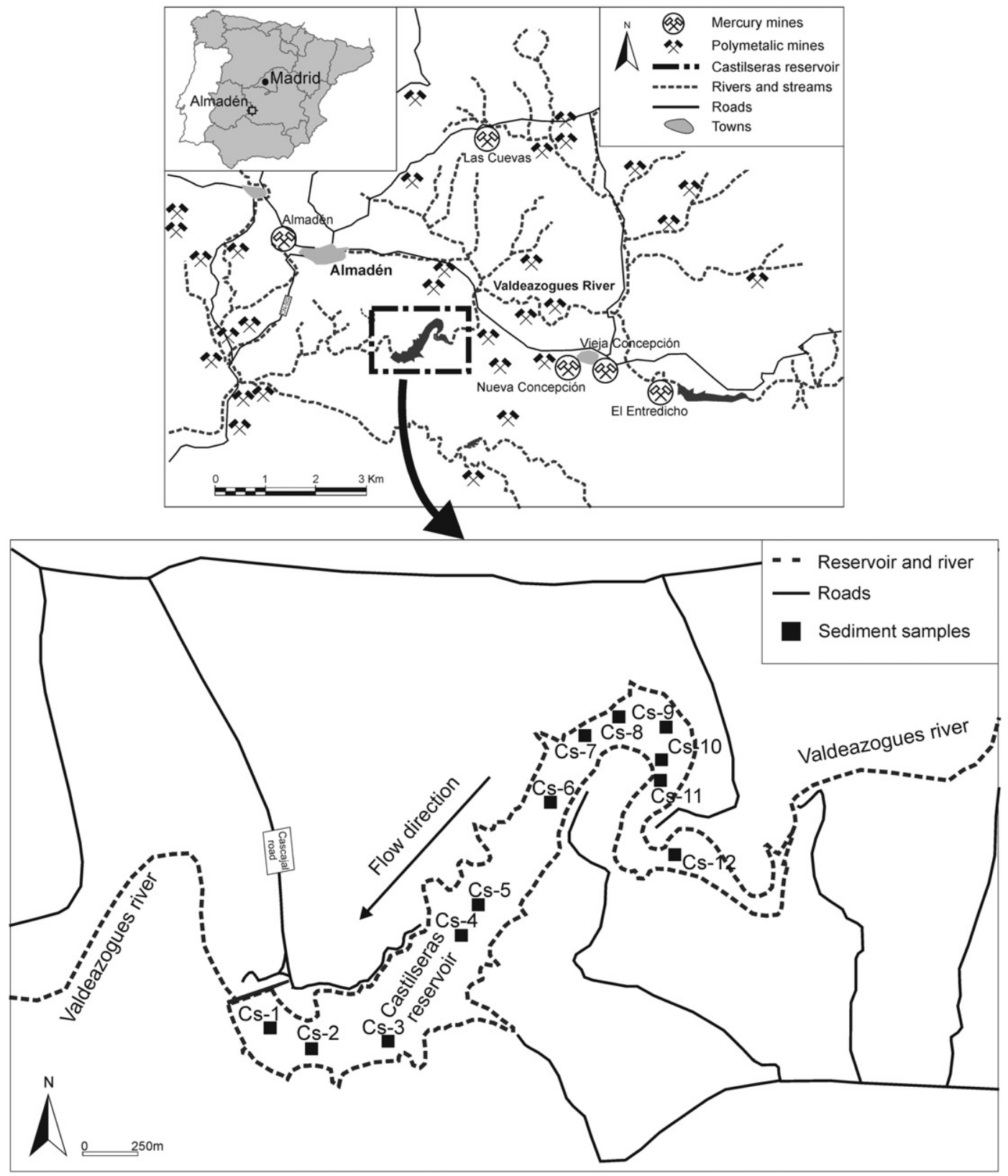

Fig. 1. Almadén mining district and study area. 
The Environment Ecological Risk (ERI) (Rapant and Kordík, 2003; Rapant et al., 2006, 2008, 2009) is a methodology that describes the potential occurrence of adverse effects as a consequence of the exposure of the environment to one or more agents of ecological stress. The ERI allows the prediction, by a numerical value, of the probability of occurrence of a negative impact in the environment by average concentrations of specific pollutants (Bhuiyan et al., 2010; Delgado et al., 2011; Nazeer et al., 2014). ERI index was calculated according to the following equations:

$E_{f}=C_{f} * T_{r}$

$E R I=\sum_{1}^{n} E_{f i}$

where $C_{f}$ is the contaminant factor; $T_{r}$ is the toxic factor response; and $E_{f}$ is the index of potential ecological risk adopted from Håkanson (1980) for the risk assessment of PTHE in the sediment.

Moreover, since different PTHE species have clearly different toxicities, the sequential leaching procedure determines the solubility of the elemental compounds present in different leachates and provides information on their geoavailability and the associated potential risk for the aquatic medium (Chen et al., 2010). In this context, sediments can be classified according to a Risk Assessment Code (RAC) developed by Perin et al. (1985). Therefore, the easiest exchangeable fraction (F1) for each element associated with sediments poses the highest risk, because it may readily enter the aquatic media and eventually bioaccumulate. According to the percentages attributed to the F1, the applied sequential extraction procedure proposed by Perin et al. (1985) classifies the elements into five groups: If $\mathrm{F} 1 \leq 1 \%$ the elements do not have a risk of transference to the trophic chain; if $1 \%<\mathrm{F} 1 \leq 10 \%$ there is low transference risk; if $10 \%<\mathrm{F} 1 \leq 30 \%$, there is a medium transference risk; if $30 \%<\mathrm{F} 1 \leq 50 \%$ there is a high transference risk; and if $\mathrm{F} 1 \geq 50 \%$, there is a very high transference risk. For a proper consideration of this potential risk, in addition of the RAC value, the values of aqua regia soluble PTHE and their comparisons with standards reported in the bibliography have been taken into account.

\section{Results and discussion}

\subsection{Geochemical characteristics and PTHE fractionation}

Range and median values of aqua regia soluble PTHE in the Castilseras reservoir sediments and from the Valdeazogues River (García-Ordiales et al., 2014) are presented in Table 1 and supplemented by selected data from the scientific literature for Spanish stream sediments (IGME, 2012) and European streams and reservoirs sediments (Håkanson, 1980; Salminen et al., 2005; De Vos et al., 2006). For most of the analyzed elements, concentration levels in the reservoir sediments are in the same order of magnitude as those found in the Valdeazogues River sediments, with the exception of $\mathrm{Hg}$, which is present at lower concentrations in the reservoir than in the fluvial environment. This evidence suggests that a major proportion of the solid contributions from the abandoned mine works, mainly consisting of coarse particles, have accumulated in stream sediments before the reservoir. When compared to stream sediments from Spain and from Europe, the concentrations of PTHE are higher in the reservoir, and this is especially apparent for some elements such as $\mathrm{Fe}, \mathrm{Hg}, \mathrm{Mg}$ and $\mathrm{Zn}$, due to the historical mining operations carried out in the district. Otherwise, when results are compared with those reported for other $\mathrm{Hg}$ mining districts, ranges of PTHE are similar to the Idrijca River (Gosar and Teršič, 2015), but the $\mathrm{Hg}$ values are much higher in the Idrija area than in Almadén. Also, comparing with Nevada Hg district (Gray et al., 1999, 2002), PTHE contents in Castilseras are much lower than those from that district.

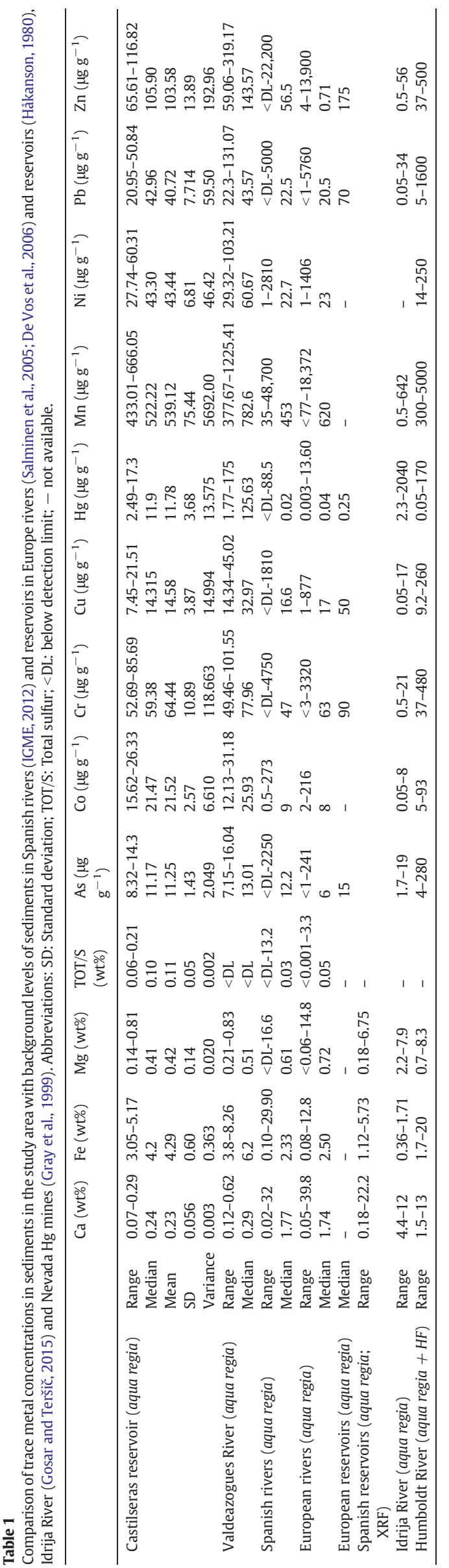


When the aqua regia PTHE concentrations measured in Castilseras sediments are compared to the standards reported in the SQRT by the US NOAA, the median values for Fe and $\mathrm{Hg}$ are higher than those corresponding to Severe Effect Levels (SEL), whereas the Ni median value exceeds the Probable Effect Level (PEL). According to these results, these elements could potentially have harmful effects on a large proportion of the benthic community and may be transferred to fish species (Ingersoll et al., 2001). The median values for $\mathrm{As}, \mathrm{Cr}, \mathrm{Mn}$ and $\mathrm{Pb}$ are higher than the Lowest Effect Level (LEL) and these elements may also affect the benthic and fish communities. The remaining analyzed elements are present at concentrations below the Threshold Effect Level (TEL), which is considered to be the maximum value to avoid potential environmental consequences on benthic and fish communities.

Taking into consideration the fact that the total concentration of elements cannot always be considered as a good indicator of the potential environmental risk (Adriano, 2001), the four fractions obtained from the SEP have been proven useful to determine the geoavailability of the mineral phases for the incorporation of PTHE into the aquatic ecosystem (Meng et al., 2016; Wei et al., 2016). The partitioning patterns (\%) of the selected elements within the operationally defined phases of the sequential extraction procedure are given in Fig. 2.

For the F1, the highest average percentages of the extract were $52 \%$, $43 \%, 41 \%, 36 \%$ and $35 \%$ for $\mathrm{Mn}, \mathrm{Ca}, \mathrm{S}, \mathrm{Zn}$ and $\mathrm{Mg}$, respectively. These elements, together with $\mathrm{As}, \mathrm{Cu}, \mathrm{Hg}$ and $\mathrm{Pb}$, which also show significant $\mathrm{F} 1$ percentages ( $>10 \%$ ), are mainly related to easy leachable mineralogical species. In the analyzed sediments, F1 may has targeted on labile chemical forms ab/adsorbed in soil particles, as well as to mineralogical species such as cerussite, calomel, schuetteite or gypsum that have been recognized in this district by Gilemany (1974) and Nuche (2003). Since neutral or slightly acidic conditions may occasionally occur in this aquatic ecosystem ( $\mathrm{pH}=5.87-9.50$ according to Berzas Nevado et al., 2003), there is an increase in geoavailability of elements which may be up-taken by plants and aquatic biota. Sulfur and zinc, according to their high average recovery in this fraction, should be in association with sulfates, which are soluble in weakly acidic environments, typical of mining areas. The high concentrations recovered of $\mathrm{Ca}$ and $\mathrm{Mg}$, together with $\mathrm{S}$, in this fraction may be attributed to the precipitation of sulfates from the mining sources by the action of cations from secondary minerals (Higueras et al., 2013) that neutralize the acidity of the aqueous system produced by mine runoff and enrich the precipitate sulfate species in the sediments (Garcia-Ordiales, 2016). However, in the same reservoir, under alkaline values of local waters (Berzas Nevado et al., 2003), the $\mathrm{Mn}^{2+}$ adsorbed on the surface of the sediments can interact with $\mathrm{CO}_{3}^{2-}$ present in the water column to form rhodochrosite (Garcia-Ordiales, 2016), which is easily leached and may be available to aquatic life. Conversely, the lowest recovery percentages in the F1 were obtained for $\mathrm{Co}, \mathrm{Cr}$ and $\mathrm{Ni}$, whose median values for total contents (21, 59 and $43 \mathrm{mg} \mathrm{kg}^{-1}$, respectively) are consistent with the local geochemical background values (García-Ordiales et al., 2014). This fact can be explained by the presence of ultramafic rocks outcropping in several parts of the district (Higueras, 1995). These rocks contain high amounts of these elements (Rawlins et al., 2012), which mainly are hosted in the silicates deriving from the weathering of these lithotypes.

In the F2 fraction related to oxy-hydroxides, high proportions of Mn and Fe were observed. This is more significant for Fe (mean recovery concentrations up to $50 \%$ of the total content, see Fig. 2) than for Mn (mean recovery concentrations up to $35 \%$ of the total content, see Fig. 2 ), due to the high enrichment of the former element in the area affected by volcanic processes during the region's geological history. These PTHE are in labile forms and they can be mobilized, together with other associated PTHE, under suboxic and anoxic conditions.

Mediterranean climates are usually characterized by drought periods with eutrophic conditions, where oxygen depletion affects the remineralization of organic matter; this is driven by other electron acceptors such as Fe and Mn oxy-hydroxides (Margalef Lopez et al., 1977). Among the other elements, As, Co and $\mathrm{Hg}$ seem to be associated with fraction F2 (average percentage recoveries were 48\%, 26\% and $17 \%$, respectively), which is related to Fe-Mn oxy-hydroxides that capture
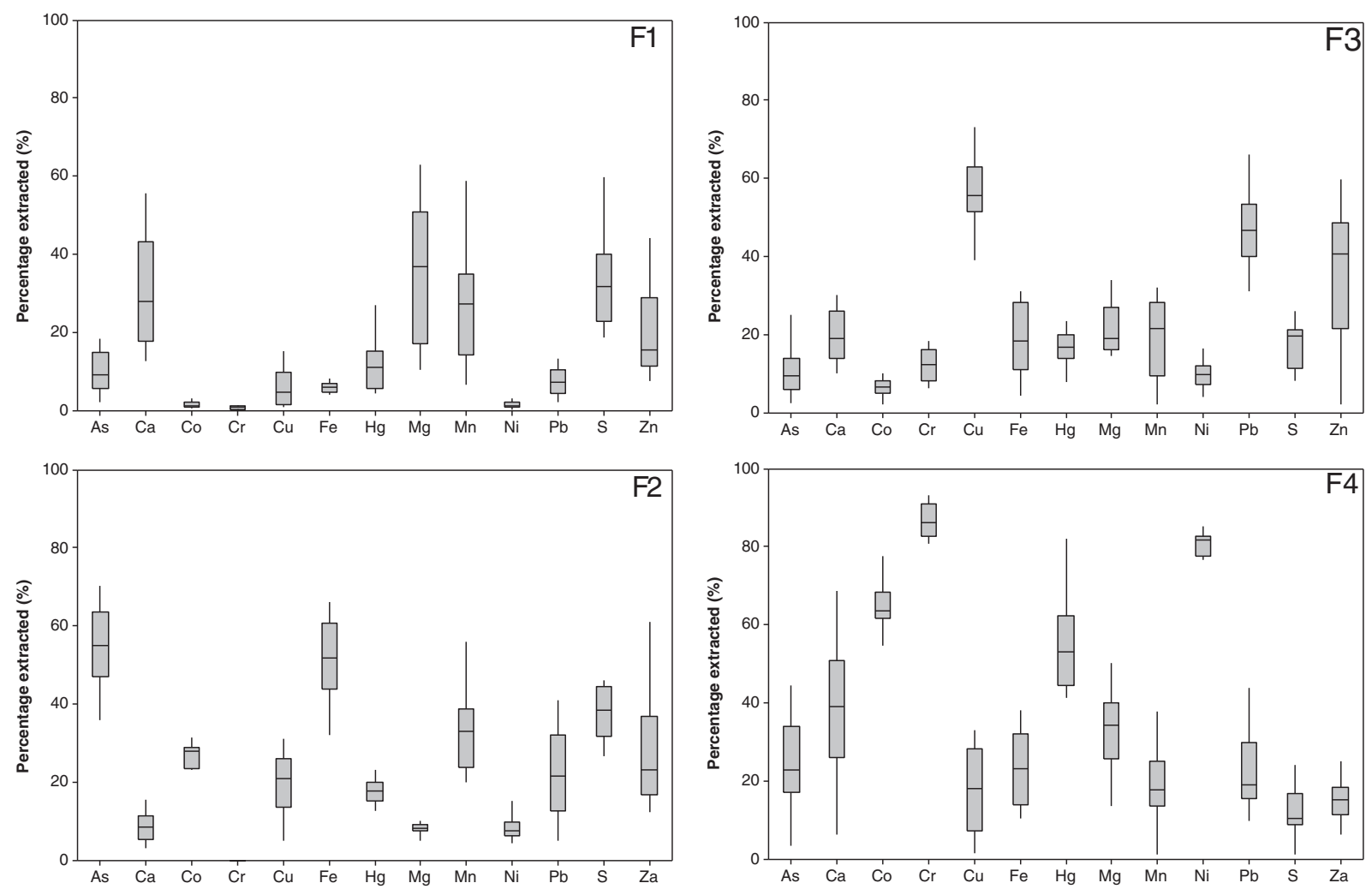

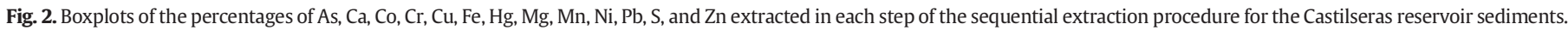


these elements and retain them in the fine grain-size fraction. Fe-Mn oxy-hydroxides are also important, but not predominant, in the retention mechanism for $\mathrm{Cu}, \mathrm{Pb}$ and $\mathrm{Zn}$, with significant recovery percentages observed for this fraction. Sulfur merits special attention in this fraction, since its average concentration is the highest among the different steps. This fact is attributed to the re-oxidation of sulphides, which takes place without direct contact with oxygen, but rather by reaction with iron or manganese oxides or other potential oxidants (Lovley, 1991). The remaining elements $(\mathrm{Ca}, \mathrm{Cr}$, $\mathrm{Ni}$ and $\mathrm{Mg}$ ) showed poor recovery percentages for this fraction.

In the $\mathrm{F} 3$, the higher recovery percentages were found for $\mathrm{Cu}, \mathrm{Pb}$ and $\mathrm{Zn}$ (56\%, $47 \%$ and $36 \%$ on average, respectively). A possible explanation is the association of these elements with the organic matter, which acts as chelating agent and as a temporary trap by controlling their mobility in the aquatic environment. This situation is characteristic of scenarios affected by anthropogenic inputs, where an increase in the As and $\mathrm{Hg}$ concentrations due to retorting can produce secondary mineral phases, which are highly water-soluble and easy bioavailability for organisms (e.g. Gray et al., 2002, 2004; Lin et al., 2010; García-Gómez et al., 2014). In contrast, Fe, Mn and S showed low average recovery percentages in this fraction, probably because they form oxy-hydroxide compounds similar to those leached in the F2 fraction. Ca and Mg (average percentage recovery is $22 \%$ and $26 \%$ respectively) in this fraction can be related to the secondary minerals that exist in the geological context of the district (Higueras, 1995). The lower recovery percentages in this fraction correspond to $\mathrm{Co}, \mathrm{Cr}$ and $\mathrm{Ni}$.
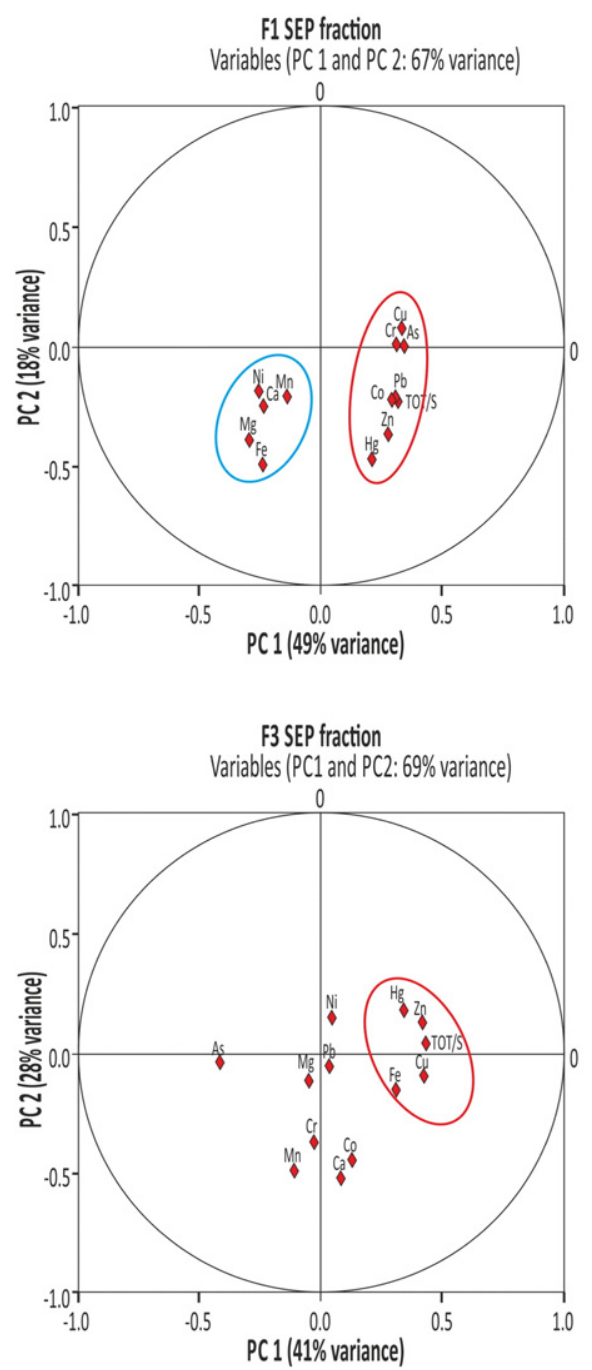

Conversely, the residual fraction (F4) exhibited high contents of Co, $\mathrm{Cr}$ and $\mathrm{Ni}$. This result, in addition to the low recovery percentages for these elements in the steps F1 + F2 + F3 (<35\%), supports the hypothesis that these elements are lithogenic and are probably associated with silicates or sulfide minerals, which in turn are related to the regional abundance of mafic magmatic rocks (Higueras et al., 2013). The rest of the elements showed average recovery percentages below $50 \%$ in the residual fraction. As a consequence, their non-residual fraction $(\mathrm{F} 1+\mathrm{F} 2+\mathrm{F} 3)$ can be regarded as an indicator of environmental risk and may be potentially transferred into the food chain. In this case, the relative percentages, which range between $45 \%$ and $88 \%$ for $\mathrm{As}, \mathrm{Ca}$, $\mathrm{Cu}, \mathrm{Fe}, \mathrm{Hg}, \mathrm{Mg}, \mathrm{Mn}, \mathrm{Pb}, \mathrm{S}$ and $\mathrm{Zn}$, suggest that these elements may be accessible for biota.

A Principal Component Analysis (PCA) was performed according to criteria explained by Preacher and MacCallum (2002) and Abdi and Williams (2010) for small datasets, to obtain more information on the relationships between elements included in each fraction. The PCA (Fig. 3) shows that the analyzed variables represent 67\%,68\%, 69\% and $71 \%$ of the total variability of samples from the SEP fractions F1, F2, F3 and F4, respectively. Fraction F1 can be differentiated into two groups with a high association level: Group I is characterized by elements such as $\mathrm{Ca}, \mathrm{Fe}, \mathrm{Mg}, \mathrm{Mn}$, and $\mathrm{Ni}$, due to the presence of secondary carbonate minerals such as ankerite, siderite, magnesite or calcite (Higueras et al., 2000), and these have a high potential capacity to collect and retain metallic elements on the surface. Group II is constituted by different elements: $\mathrm{As}, \mathrm{Co}, \mathrm{Cu}, \mathrm{Hg}, \mathrm{Pb}, \mathrm{TOT} / \mathrm{S}$ and $\mathrm{Zn}$ that do not show a clear
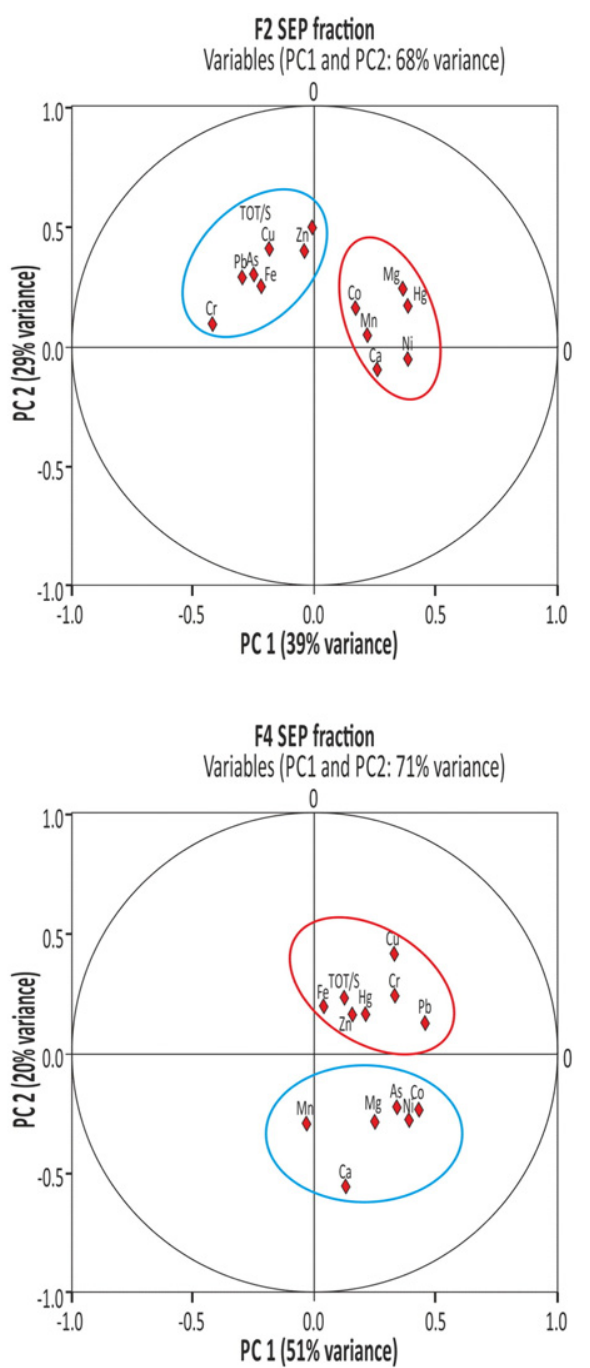

Fig. 3. Presentation of the principal component analysis (PCA) for the different steps recovered in the SEP. Alpha significance level $<0.05$. 

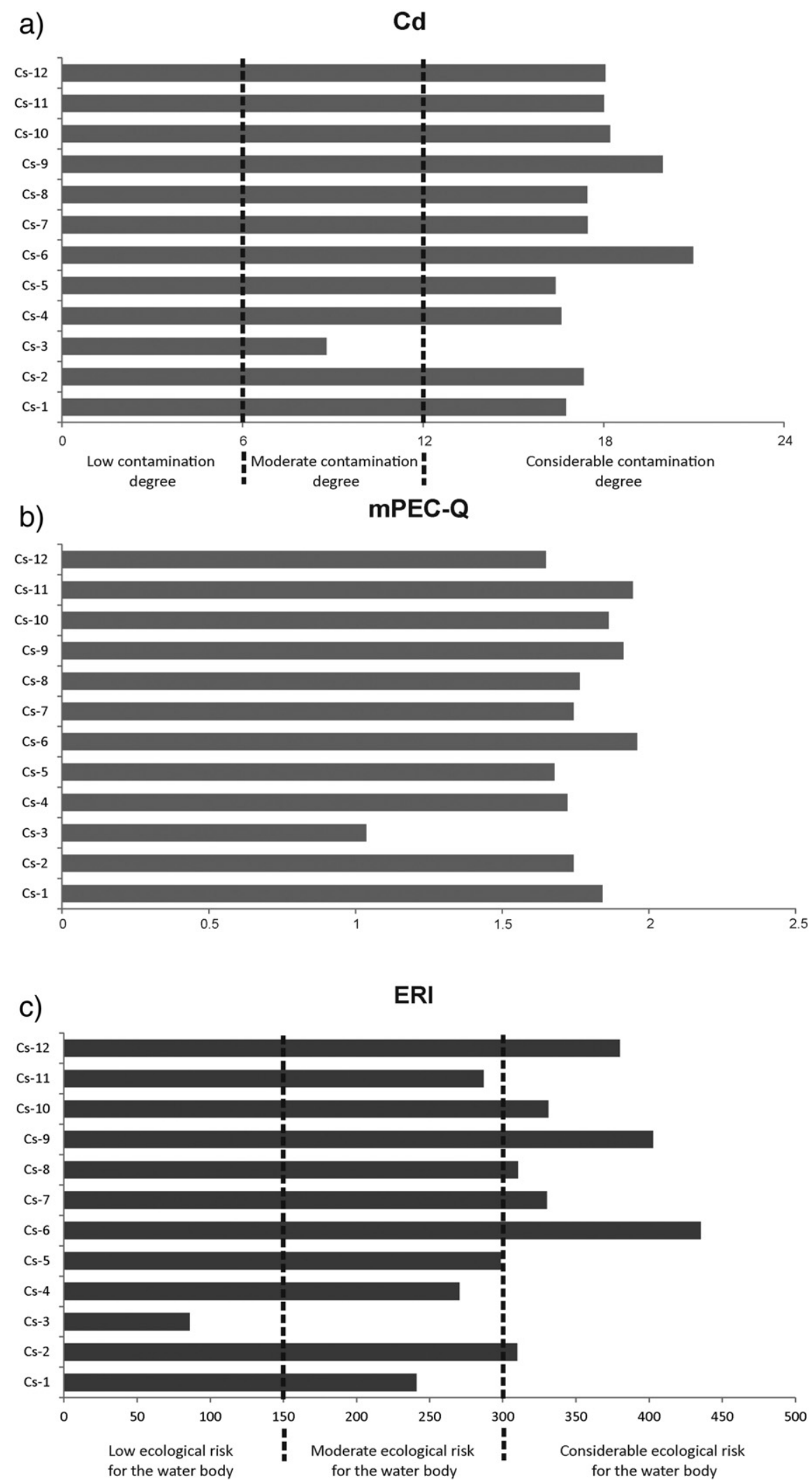

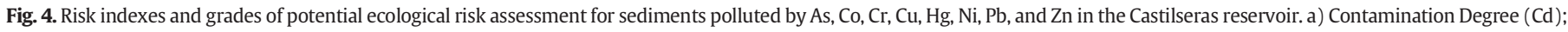
b) mean probable effect concentration quotient index (mPEC-Q); c) Environment Ecological Risk (ERI).

association and could form a mixing group where different mineral species such as hydrated oxides of iron and manganese, humic acids o sulfates.

The results for the F2 fraction distinguish the elements into two groups, which are formed by a mixing of different mineralogical species.
Group I is constituted by $\mathrm{As}, \mathrm{Cr}, \mathrm{Cu}, \mathrm{Fe}, \mathrm{Pb}, \mathrm{S}$ and $\mathrm{Zn}$, which can be attributed to the important role proposed for Fe oxy-hydroxides in the retention of PTHE in this fraction and in the case of S, their contents recovery in this fraction may be due to sulfate species that remain after the first step. Group II contains elements such as $\mathrm{Ca}, \mathrm{Co}, \mathrm{Mn}$ and Ni, which are 
associated with carbonate and/or possible Mn oxides rather than Fe oxy-hydroxides (Pickering, 1979; Lienemann et al., 1997).

Analysis of the F3 fraction does not show as clear differentiation as the other fractions. It seems that $\mathrm{Cu}, \mathrm{Fe}, \mathrm{Hg}$ and $\mathrm{Zn}$, in this fraction are associated with sulfides and organic matter, considering their propensity to form organometallic compounds (Adriano, 2001).

Finally, analysis of the residual fraction F4 showed a clear differentiation of the elements into two groups. The first group consists of As, Ca, $\mathrm{Co}, \mathrm{Mg}, \mathrm{Mn}$ and $\mathrm{Ni}$, in which major part of elements are related to the presence of silicates (Sherman and Randall, 2003; Zakir and Shikazono, 2011) except As, which could be related to other recalcitrant minerals (Akai et al., 2004). The second group is composed by $\mathrm{Cr}, \mathrm{Cu}, \mathrm{Fe}$, $\mathrm{Hg}, \mathrm{Pb}, \mathrm{S}$ and $\mathrm{Zn}$, which are recognized as having an affinity with sulfides or secondary sulfates.

\subsection{Ecological risk assessment}

The calculated values for the different environmental indexes used for the elements $\mathrm{As}, \mathrm{Co}, \mathrm{Cr}, \mathrm{Cu}, \mathrm{Hg}, \mathrm{Ni}, \mathrm{Pb}$ and $\mathrm{Zn}$ are presented in Fig. 4. The results obtained from the $\mathrm{Cd}$ index (Fig. 4a), which was calculated with respect to the regional geochemical background (García-Ordiales et al., 2014), reveals a homogeneous degradation of the sediment quality for most of the sampling points. This situation is significantly more adverse in Cs6 (21.0) and Cs9 (20.0).

The mPEC-Q (Fig. 4b), shows values higher than 0.5 in all cases, which is indicative of pollution by PTHE (EC and MENVIQ 1992; Fu et al., 2014). The average contributions for each of the most representative elements are $\mathrm{Hg}(87.7 \%)>\mathrm{Ni}(3.4 \%)>\mathrm{As}(2.7 \%)>\mathrm{Cr}(2.4 \%)>\mathrm{Pb}$ $(1.6 \%)>\mathrm{Zn}(1.2 \%)>\mathrm{Co}(0.6 \%)>\mathrm{Cu}(0.5 \%)$. On the basis of previous considerations, $\mathrm{Ni}, \mathrm{Cr}$ and $\mathrm{Co}$ concentrations could be considered lithogenic that is supplied by a natural source.

Despite the interest that these indexes have attracted in representing the potential environmental risk, none of them takes in consideration the toxic response of the elements (Zhu et al., 2012). These indexes are based primarily on biological processes, which may transform chemicals into other more toxic compounds and on the basis of tissues or organs participating in the accumulation patterns of PTHE (Håkanson, 1980). For this reason, the ERI explained in previous paragraphs seems to be the best choice to provide a reasonably reliable assessment.

With the exception of Cs3, which is affected by a low ecological risk, the ERI values obtained from the analyzed samples (Fig. 4c) fall within the range that identifies an ecological risk from moderate to considerable. According to this index, and considering the whole group of samples, a gradual decrease in the risk assessment is observed from the head of the reservoir (from Cs12 to Cs6) downstream to the dam (from Cs5 to Cs1).

Finally, considering the sequential extraction for the characterization of potential risk of the sediment, according to the RAC (Wang et al., 2016) (Table 2) and aqua regia soluble PTHE contents respect to the standards reported in the bibliography, $\mathrm{Hg}$ exhibits a global very high ecological risk, since all its values are up to the SEL, and the RAC $\left(\mathrm{F} 1_{\mathrm{m}}=11.3 \%\right)$ consider its potential transference risk as moderate. $\mathrm{Ni}$ and $\mathrm{Zn}$ were the elements which presents a global moderate ecological risk as result of its aqua regia soluble contents in sediments are up to the PEL in case of $\mathrm{Ni}$, and the RAC $\left(\mathrm{F} 1_{\mathrm{m}}=20 \%\right)$ was considered ecological risk of transfer for $\mathrm{Zn}$. The rest of analyzed elements, such as As $\left(\mathrm{F} 1_{\mathrm{m}}=9.9 \%\right), \mathrm{Co}(1.7 \%), \mathrm{Cr}\left(\mathrm{F} 1_{\mathrm{m}}=0.8 \%\right), \mathrm{Cu}\left(\mathrm{F} 1_{\mathrm{m}}=6.1 \%\right)$, and $\mathrm{Pb}$ $\left(\mathrm{F} 1_{\mathrm{m}}=7.5 \%\right)$, displayed a global low or null risk of transfer, since their aqua regia soluble contents were low to the LEL and their RAC values showed a low or no risk of transfer.

\section{Conclusions}

There is no doubt that the Castilseras reservoir plays an important hydrological role within the Valdeazogues River watershed. The reservoir acts as a trap for fluvial sediments and, consequently, it behaves as a sink for associated PTHE. Although mining activity stopped almost ten years ago, the upper course of the Valdeazogues River remains an active contamination source for the freshwater environment. The high contents in $\mathrm{Hg}$ and other PTHE, mainly As and $\mathrm{Pb}$, compared with regional values, may be attributed to environmental liabilities of the several decommissioned mines present in the area. According to the sediment quality guidelines applied in this study, aqua regia soluble concentrations of some elements ( $\mathrm{Fe}, \mathrm{Hg}$ and $\mathrm{Mn}$ ) exceed the most restricted advised levels, whereas for other elements ( $\mathrm{As}, \mathrm{Cr}, \mathrm{Ni}$, and $\mathrm{Pb}$ ) the contents fall within values that are consistent with the probable or

Table 2

Risk assessment codes (RAC) for Castilseras reservoir sediments. All values in \%.

\begin{tabular}{|c|c|c|c|c|c|c|c|c|c|}
\hline & & $\mathrm{Cu}$ & $\mathrm{Pb}$ & $\mathrm{Zn}$ & $\mathrm{Ni}$ & Co & As & $\mathrm{Cr}$ & $\mathrm{Hg}$ \\
\hline \multirow[t]{2}{*}{ Cs-1 } & F1 (\%) & 8.2 & 13.3 & 44.2 & 0.9 & 3.1 & 16.3 & 1.2 & 27.0 \\
\hline & RAC & Low risk & Moderate risk & High risk & No risk & Low risk & Moderate risk & Low risk & Moderate risk \\
\hline \multirow[t]{2}{*}{ Cs-2 } & F1 () & 15.3 & 10.8 & 31.2 & 1.1 & 1.1 & 14.4 & 1.0 & 17.3 \\
\hline & RAC & Moderate risk & Moderate risk & High risk & Low risk & Low risk & Moderate risk & No risk & Moderate risk \\
\hline \multirow{2}{*}{ Cs-3 } & $\mathrm{F} 1()$ & 9.3 & 6.3 & 12.5 & 1.2 & 1.4 & 8.2 & 0.9 & 5.2 \\
\hline & RAC & Low risk & Low risk & Moderate risk & Low risk & Low risk & Low risk & No risk & Low risk \\
\hline \multirow[t]{2}{*}{ Cs-4 } & $\mathrm{F} 1()$ & 10.2 & 12.5 & 14.2 & 2.3 & 0.8 & 10.1 & 0.8 & 11.5 \\
\hline & RAC & Moderate risk & Moderate risk & Moderate risk & Low risk & No risk & Moderate risk & No risk & Moderate risk \\
\hline \multirow[t]{2}{*}{ Cs-5 } & $\mathrm{F} 1()$ & 12.4 & 8.2 & 7.6 & 1.2 & 0.9 & 18.4 & 1.3 & 10.7 \\
\hline & RAC & Moderate risk & Low risk & Low risk & Low risk & No risk & Moderate risk & Low risk & Moderate risk \\
\hline \multirow[t]{2}{*}{ Cs-6 } & $\mathrm{F} 1()$ & 6.2 & 10.1 & 22.1 & 0.8 & 0.8 & 5.7 & 0.5 & 12.4 \\
\hline & RAC & Low risk & Moderate risk & Moderate risk & No risk & No risk & Low risk & No risk & Moderate risk \\
\hline \multirow[t]{2}{*}{ Cs-7 } & $\mathrm{F} 1()$ & 2.2 & 7.2 & 25.0 & 1.5 & 1.4 & 12.1 & 0.7 & 5.5 \\
\hline & RAC & Low risk & Low risk & Moderate risk & Low risk & Low risk & Moderate risk & No risk & Low risk \\
\hline \multirow[t]{2}{*}{ Cs-8 } & $\mathrm{F} 1()$ & 3.3 & 3.2 & 30.2 & 0.2 & 2.1 & 15.2 & 1.2 & 12.0 \\
\hline & RAC & Low risk & Low risk & High risk & No risk & Low risk & Moderate risk & Low risk & Moderate risk \\
\hline \multirow[t]{2}{*}{ Cs-9 } & F1 ( ) & 1.1 & 4.3 & 10.8 & 2.4 & 1.4 & 5.6 & 1.0 & 6.1 \\
\hline & RAC & Low risk & Low risk & Moderate risk & Low risk & Low risk & Low risk & Low risk & Low risk \\
\hline \multirow[t]{2}{*}{ Cs-10 } & $\mathrm{F} 1()$ & 2.4 & 2.2 & 11.1 & 3.3 & 2.2 & 7.3 & 0.5 & 4.4 \\
\hline & RAC & Low risk & Low risk & Moderate risk & Low risk & Low risk & Low risk & No risk & Low risk \\
\hline \multirow[t]{2}{*}{ Cs-11 } & $\mathrm{F} 1()$ & 1.2 & 7.3 & 17.1 & 2.2 & 3.2 & 2.2 & 0.3 & 16.3 \\
\hline & RAC & Low risk & Low risk & Moderate risk & Low risk & Low risk & Low risk & No risk & Moderate risk \\
\hline \multirow[t]{2}{*}{ Cs-12 } & $\mathrm{F} 1()$ & 1.0 & 5.1 & 14.2 & 1.8 & 2.1 & 3.2 & 0.4 & 6.8 \\
\hline & RAC & No risk & Low risk & Moderate risk & Low risk & Low risk & Low risk & No risk & Low risk \\
\hline \multirow[t]{2}{*}{ Mean } & $\mathrm{F} 1()$ & 6.1 & 7.5 & 20.0 & 1.6 & 1.7 & 9.9 & 0.8 & 11.3 \\
\hline & RAC & Low risk & Low risk & Moderate risk & Low risk & Low risk & Low risk & No risk & Moderate risk \\
\hline
\end{tabular}


lowest harmful effect levels observable on biota. In addition, speciation techniques highlighted the presence of the labile and potentially available fractions as significantly high (35-50\%) for $\mathrm{Ca}, \mathrm{Mg}, \mathrm{Mn}, \mathrm{S}$ and $\mathrm{Zn}$ and fairly significant $(>10 \%$ ) for $\mathrm{As}, \mathrm{Cu}, \mathrm{Hg}$ and $\mathrm{Pb}$. Conversely, only $\mathrm{Co}, \mathrm{Cr}$ and $\mathrm{Ni}$ exhibited high contents in the residual fraction and these can be considered as virtually unavailable to the biotic compartment.

The environmental risk assessment based on several indexes that provide a global evaluation of sediments from the ecological point of view reveals that risk levels vary from moderate to high and they increase in the lower section of the reservoir close to the dam. The high potential risk of the remobilization of PTHE from sediments into the water column and their subsequent bioaccumulation in the trophic chain are also enhanced by the abundance of animal and plant species in this freshwater ecosystem. Since recreational fishing is a common practice in the reservoir and within the river watershed, the ultimate risk is the potential uptake of PTHE by the resident population through fish consumption. In this context, sediments may play an important role as a secondary source of PTHE in relation to the biogeochemical processes occurring at the sediment water-interface, which are almost entirely mediated by microbial activity, such as methylation of $\mathrm{Hg}$. As the presence of PTHE in the reservoir sediments must be considered to be a permanent issue, future research should be directed towards the biogeochemical behavior of these PTHE in the sediment-water system to help to understand how to mitigate the present risk of this drainage basin.

\section{Funding}

This study was supported by the Spanish Ministry of Science and Innovation (grant numbers: BES-2010-040450; CGL2009-13171-C03-03; CTM 2012-33918 and EEBB-I-13-07336) and by the Asturias Regional Ministry of Education and Science (grant number: ECOEMP-2013).

\section{Acknowledgements}

The authors would like to acknowledge the support of the MAYASA mining company, Juan Camacho Díez and Ahmet Emin for their collaboration in sampling works. The authors are very grateful for critical comments and suggestions of two anonymous reviewers, which greatly improved the early version of the manuscript and also, the revision of English style by the Professor Malcom R. Gent.

\section{Appendix A. Supplementary data}

Supplementary data to this article can be found online at http://dx. doi.org/10.1016/j.catena.2016.07.042.

\section{References}

Abdi, H., Williams, L.J., 2010. Principal component analysis. Wiley interdisciplinary reviews. Comput. Stat. 2 (4), 433-459.

Abrahim, G.M.S., 2005. Holocene sediments of Tamaki Estuary: characterization and impact of recent human activity on an urban estuary in Auckland, New Zealand (PhD Thesis) University of Auckland, Auckland (New Zealand).

Acosta, J.A., Cano, A.F., Arocena, J.M., Debela, F., Martínez-Martínez, S., 2009. Distribution of metals in soil particle size fractions and its implication to risk assessment of playgrounds in Murcia City (Spain). Geoderma 149 (1), 101-109.

Adriano, D.C., 2001. Trace Elements in Terrestrial Environments; Biogeochemistry, Bioavailability and Risks of Metals. second ed. Springer, New York.

Akai, J., Izumi, K., Fukuhara, H., Masuda, H., Nakano, S., Yoshimura, T., ... Akai, K., 2004. Mineralogical and geomicrobiological investigations on groundwater arsenic enrichment in Bangladesh. Appl. Geochem. 19 (2), 215-230.

Bavec, Š., Biester, H., Gosar, M., 2014. Urban sediment contamination in a former Hg mining district, Idrija, Slovenia. Environ. Geochem. Health 36 (3), 427-439.

Berzas Nevado, J.J., García Bermejo, L.F., Rodríguez Martín-Doimeadios, R.C., 2003. Distribution of mercury in the aquatic environment at Almadén, Spain. Environ. Pollut. 122 (2), 261-271.

Bhuiyan, M.A.H., Parvez, L., Islam, M.A., Dampare, S.B., Suzuki, S., 2010. Heavy metal pollution of coal mine-affected agricultural soils in the northern part of Bangladesh. J. Hazard. Mater. 173 (1-3), 384-392.
Brockhoff, C.A., Creed, J.T., Martin, T.D., Martin, E.R., Long, S.E., 1999. EPA Method 200.8 Revision 5.5: Determination of trace metals in waters and wastes by inductively coupled plasma-mass spectrometry Vol. 61 (EPA-821R-99-017).

Buchman, M.F., 2008. NOAA Screening Quick Reference Tables, NOAA OR\&R Report 08-1. Office of Response and Restoration Division, National Oceanic and Atmospheric Administration, Seattle WA.

Chen, C., Lu, Y., Hong, J., Ye, M., Wang, Y., Lu, H., 2010. Metal and metalloid contaminant availability in Yundang Lagoon sediments, Xiamen Bay, China, after 20 years continuous rehabilitation. J. Hazard. Mater. 175 (1-3), 1048-1055.

Costley, C.T., Mossop, K.F., Dean, J.R., Garden, L.M., Marshall, J., Carroll, J., 2000. Determination of mercury in environmental and biological samples using pyrolysis atomic absorption spectrometry with gold amalgamation. Anal. Chim. Acta 405 (1), 179-183.

Covelli, S., Langone, L., Acquavita, A., Piani, R., Emili, A., 2012. Historical flux of mercury associated with mining and industrial sources in the Marano and Grado Lagoon (northern Adriatic sea). Estuar. Coast. Shelf Sci. 13, 7-19.

Dago, À., González, I., Ariño, C., Martínez-Coronado, A., Higueras, P., Diaz-Cruz, J.M. Esteban, M., 2014. Evaluation of mercury stress in plants from the Almadén mining district by analysis of phytochelatins and their $\mathrm{Hg}$ complexes. Environ. Sci. Technol. 48 (11), 6256-6263.

De Vos, W. and Tarvainen, T., chief eds., Salminen, R., Reeder, S., De Vivo, B., Demetriades A., Pirc, S., Batista, M.J., Marsina, K., Ottesen, R.T., O'Connor, P.J., Bidovec, M., Lima, A. Siewers, U., Smith, B., Taylor, H., Shaw, R., Salpeteur, I., Gregorauskiene, V., Halamic, J, Slaninka, I., Lax, K., Gravesen, P., Birke, M., Breward, N., Ander, E.L., Jordan, G., Duris, M., Klein, P., Locutura, J., Bel-Ian, A., Pasieczna, A., Lis, J., Mazreku, A., Gilucis, A. Heitzmann, P., Klaver, G. and Petersell, V., 2006, Geochemical Atlas of Europe. Part 2 - Interpretation of Geochemical Maps, Additional Tables, Figures, Maps, and Related Publications: Geological Survey of Finland, Espoo.

Delgado, J., Barba-Brioso, C., Nieto, J.M., Boski, T., 2011. Speciation and ecological risk of toxic elements in estuarine sediments affected by multiple anthropogenic contributions (Guadiana saltmarshes, SW Iberian Peninsula): I. Surficial sediments. Sci. Total Environ. 409 (19), 3666-3679.

Dević, G., Sakan, S., Đorđević, D., 2016. Assessment of the environmental significance of nutrients and heavy metal pollution in the river network of Serbia. Environ. Sci. Pollut. Res. 23 (1), 282-297.

Dhanakumar, S., Solaraj, G., Mohanraj, R., 2015. Heavy metal partitioning in sediments and bioaccumulation in commercial fish species of three major reservoirs of river Cauvery delta region, India. Ecotoxicol. Environ. Saf. 113, 145-151.

Duan, L., Song, J., Xu, Y., Li, X., Zhang, Y., 2010. The distribution, enrichment and source of potential harmful elements in surface sediments of Bohai Bay, North China. J. Hazard. Mater. 183 (1), 155-164.

EC \& MENVIQ (Environmental Canada and Ministere de l'Environnement du Quebec) 1992o. Interin Criteria for Quality Assessment of St. Lawrence River Sediments. Environ Canada. Ottawa, Ontario.

EU, 2001. Pollutants in urban waste water and sewage sludge. 2. Potentially toxic elements: sources, pathways, and fate through urban wastewater treatment systems. Availaible on http://ec.europa.eu/environment/waste/sludge/pdf/sludge_pollutants_2.pdf.

Fang, H., Huang, L., Wang, J., He, G., Reible, D., 2016. Environmental assessment of heavy metal transport and transformation in the Hangzhou Bay, China. J. Hazard. Mater. 302, 447-457.

Fu, J., Zhao, C., Luo, Y., Liu, C., Kyzas, G.Z., Luo, Y., Zhao, D., An, S., Zhu, H., 2014. Heavy metals in surface sediments of the Jialu River, China: their relations to environmental factors. J. Hazard. Mater. 270, 102-109.

García-Gómez, C., Esteban, E., Sánchez-Pardo, B., Fernández, M.D., 2014. Assessing the ecotoxicological effects of long-term contaminated mine soils on plants and earthworms: relevance of soil (total and available) and body concentrations. Ecotoxicology 1-15 23 (7), 1195-1209.

Garcia-Ordiales, E., 2016. Incidencia de la minería abandonada en la cuenca del Rio Valdeazogues y valoración del impacto en el sistema acuático. Escuela de Ingeniería de Minas, Energía y Materiales. Universidad de Oviedo Ed., Grupo Hunosa. ISBN: 978-84-608-6349-6 (In Spanish).

García-Ordiales, E., Loredo, J., Esbrí, J.M., Lominchar, M.A., Millán, R., Higueras, P., 2014 Stream bottom sediments as a mean to assess metal contamination in the historic mining district of Almadén (Spain). Int. J. Min. Reclam. Environ. 28 (6), 357-376.

Gilemany, J.M., 1974. Estructura y mineralogénesis del mineral de mercurio de Almadén (PhD Thesis) University of Barcelona, Barcelona (Spain) (In spanish).

Gosar, M., 2008. Mercury in river sediments, floodplains and plants growing thereon in drainage area of Idrija mine, Slovenia. Pol. J. Environ. Stud. 17 (2), 227.

Gosar, M., Teršič, T., 2015. Contaminated sediment loads from ancient mercury ore roasting sites, Idrija area, Slovenia. J. Geochem. Explor. 149, 97-105.

Gosar, M., Pirc, S., Bidovec, M., 1997. Mercury in the Idrijca River sediments as a retention of mining and smelting activities of the Idrija mercury mine. J. Geochem. Explor. 58, $125-131$.

Gray, J.E., Adams, M.G., Crock, J.G., Theodorakos, P.M., 1999. Digital geochemical data for environmental studies of mercury mines in Nevada. US Geol. Surv. Open-File Report, pp. 99-576.

Gray, J.E., Crock, J.G., Fey, D.L., 2002. Environmental geochemistry of abandoned mercury mines in West-Central Nevada, USA. Appl. Geochem. 17, 1069-1079.

Gray, J.E., Hines, M.E., Higueras, P.L., Adatto, I., Lasorsa, B.K., 2004. Mercury speciation and microbial transformations in mine wastes, stream sediments, and surface waters at the Almadén Mining District, Spain. Environ. Sci. Technol. 38 (16), 4285-4292.

Gray, J.E., Rimondi, V., Costagliola, P., Vaselli, O., Lattanzi, P., 2014. Long-distance transport of $\mathrm{Hg}, \mathrm{Sb}$, and As from a mined area, conversion of $\mathrm{Hg}$ to methyl-Hg, and uptake of $\mathrm{Hg}$ by fish on the Tiber River basin, west-central Italy. Environ. Geochem. Health 36 (1), 145-157.

Håkanson, L., 1980. An ecological risk index for aquatic pollution control. A sedimentological approach. Water Res. 14, 975-1001. 
Hernández, A., Jébrak, M., Higueras, P., Oyarzun, R., Morata, D., Munhá, J., 1999. The Almadén mercury mining district, Spain. Mineral. Deposita 34 (5-6), 539-548.

Higueras, P., 1995. Procesos petrogenéticos y de alteración de las rocas magmáticas asociadas a las mineralizaciones de mercurio del Distrito de Almadén (PhD Thesis) University of Castilla-La Mancha, Ciudad Real (Spain) (In Spanish).

Higueras, P., Oyarzun, R., Munhá, J., Morata, D., 2000. The Almadén mercury metallogenic cluster (Ciudad Real, Spain): alkaline magmatism leading to mineralization processes at an intraplate tectonic setting. Rev. Soc. Geol. Esp. 13 (1), 105-119.

Higueras, P., Oyarzun, R., Lillo, J., Sánchez-Hernández, J.C., Molina, J.A., Esbrí, J.M., Lorenzo, S., 2006. The Almaden district (Spain): Anatomy of one of the world's largest hg-contaminated sites. Sci. Total Environ. 356 (1-3), 112-124.

Higueras, P., Oyarzun, R., Iraizoz, J.M., Lorenzo, S., Esbrí, J.M., Martínez Coronado, A., 2011. Low-cost geochemical surveys for environmental studies in developing countries: testing a field portable FRX instrument under quasi-realistic conditions. J. Geochem. Explor. 113, 3-12.

Higueras, P.L., Esbri, J.M., Gonzalez-Corrochano, B., Lopez-Berdonces, M.A., GarcíaNoguero, E.M., Martinez-Coronado, A., Llanos, W., Lorenzo, S., 2012. Consideraciones ambientales sobre el mercurio en el distrito minero de Almadén (Ciudad Real, España). De Re Metallica 19, 53-65 (In Spanish).

Higueras, P., Oyarzun, R., Lillo, J., Morata, D., 2013. Intraplate mafic magmatism, degasification, and deposition of mercury: the giant Almadén mercury deposit (Spain) revisited. Ore Geol. Rev. 51, 93-102.

IGME, 2012. Geochemical atlas of Spain (Atlas Geoquímico de España). Instituto Geológico y Minero de España, Madrid In Spanish.

Ingersoll, C.G., MacDonald, D.D., Wang, N., Crane, J.L., Field, L.J., Haverland, P.S., Kamble, N.E., Lindskoog, R.A., Severn, C., Smorong, D.E., 2001. Predictions of sediment toxicity using consensus-based freshwater sediment quality guidelines. Arch. Environ. Contam. Toxicol. 41 (1), 8-21.

Lechler, P.J., Miller, J.R., Hsu, L.C., Desilets, M.O., 1997. Mercury mobility at the Carson River Superfund Site, west-central Nevada, USA: interpretation of mercury speciation data in mill tailings, soils, and sediments. J. Geochem. Explor. 58 (2), 259-267.

Li, X., Thornton, I., 2001. Chemical partitioning of trace and major elements in soils contaminated by mining and smelting activities. Appl. Geochem. 16 (15), 1693-1706.

Lienemann, C.P., Taillefert, M., Perret, D., Gaillard, J.F., 1997. Association of cobalt and manganese in aquatic systems: chemical and microscopic evidence. Geochim. Cosmochim. Acta 61 (7), 1437-1446.

Lin, Y., Larssen, T., Vogt, R.D., Feng, X., 2010. Identification of fractions of mercury in water, soil and sediment from a typical Hg mining area in Wanshan, Guizhou province, China. Appl. Geochem. 25 (1), 60-68.

Liu, J., Li, Y., Zhang, B., Cao, J., Cao, Z., Domagalski, J., 2009. Ecological risk of heavy metals in sediments of the Luan River source water. Ecotoxicology 18 (6), 748-758.

Loska, K., Wiechuła, D., 2003. Application of principal component analysis for the estimation of source of heavy metal contamination in surface sediments from the Rybnik Reservoir. Chemosphere 51 (8), 723-733.

Lovley, D.R., 1991. Dissimilatory Fe (III) and Mn (IV) reduction. Microbiol. Rev. 55 (2) 259-287.

MacDonald, D.D., Ingersoll, C.G., Berger, T.A., 2000. Development and evaluation of consensus-based sediment quality guidelines for freshwater ecosystems. Arch. Environ. Contam. Toxicol. 39, 20-31.

Margalef Lopez, R., Planas Mont, D., Armengol Bachero, J., Vidal Celma, A., Prat Fornells, N. 1977. Limnología de los embalses españoles. Dirección General de Obras Hidráulicas, Ministerio de Obras Públicas (In Spanish)

Meng, Q., Zhang, J., Feng, J., Zhang, Z., Wu, T., 2016. Geochemical speciation and risk assessment of metals in the river sediments from Dan River Drainage, China. Chem. Ecol. 1-17.

Michalec, B., 2012. Qualitative and Quantitative Assessment of Sediments Pollution with Heavy Metals of Small Water Reservoirs. Soil Health and Land Use Management. INTECH Open Access Publisher.

Millán, R., Gamarra, R., Schmid, T., Sierra, M.J., Quejido, A.J., Sánchez, D.M., Cardona, A.I., Fernández, M., Vera, R., 2006. Mercury content in vegetation and soils of the Almadén mining area (Spain). Sci. Total Environ. 368 (1), 79-87.

Millán, R., Lominchar, M.A., Rodríguez-Alonso, J., Schmid, T., Sierra, M.J., 2012. Riparian vegetation role in mercury uptake (Valdeazogues River, Almadén, Spain). J. Geochem. Explor. 140, 104-110.

Molina, J.A., Oyarzun, R., Esbrí, J.M., Higueras, P., 2006. Mercury accumulation in soils and plants in the Almadén mining district, Spain: one of the most contaminated sites on Earth. Environ. Geochem. Health 28 (5), 487-498.

Nazeer, S., Hashmi, M.Z., Malik, R.N., 2014. Heavy metals distribution, risk assessment and water quality characterization by water quality index of the River Soan, Pakistan. Ecol. Indic. 43, 262-270.

Nuche, R., 2003. Patrimonio geológico de Castilla-La Mancha. ENRESA, Madrid (In spanish).

Perin, G., Craboledda, L., Lucchese, M., Cirillo, R., Dotta, L., Zanette, M.L., Orio, A.A., 1985 Heavy metal speciation in the sediments of Northern Adriatic Sea - a new approach for environmental toxicity determination. In: Lekkas, T.D. (Ed.), Heavy Metals in the Environment, pp. 454-466.

Pettine, M., La Noce, T., Macchi, G., Millero, F.J., 1982. Heavy metals in the Tiber river basin. Mar. Pollut. Bull. 13 (9), 327-329.

Pickering, W.F., 1979. Copper retention by soil/sediment components. In: Nriagu, J.O. (Ed.), Copper in the environment. I. Ecological cycling. John Wiley, New York, pp. 217-253.
Preacher, K.J., MacCallum, R.C., 2002. Exploratory factor analysis in behavior genetics research: factor recovery with small sample sizes. Behav. Genet. 32 (2), 153-161.

Quevauviller, P., Rauret, G., López-Sánchez, J.F., Rubio, R., Ure, A., Muntau, H., 1997. Certification of trace metal extractable contents in a sediment reference material (CRM 601 ) following a three-step sequential extraction procedure. Sci. Total Environ. 205 (2), 223-234.

Rapant, S., Kordík, J., 2003. An environmental risk assessment map of the Slovak Republic: application of data from geochemical atlases. Environ. Geol. 44 (4), 400-407.

Rapant, S., Dietzová, Z., Cicmanová, S., 2006. Environmental and health risk assessment in abandoned mining area, Zlata Idka, Slovakia. Environ. Geol. 51 (3), 387-397.

Rapant, S., Salminen, R., Tarvainen, T., Krmová, K., Cveková, V., 2008. Application of a risk assessment method to Europe-wide geochemical baseline data. Geochem. Explor. Environ. Anal. 8, 291-299.

Rapant, S., Bodiš, D., Vrana, K., Cvečková, V., Kordík, J., Krčmová, K., Slaninka, I., 2009. Geochemical Atlas of Slovakia and examples of its applications to environmental problems. Environ. Geol. 57, 99-110.

Rawlins, B.G., McGrath, S.P., Scheib, A.J., Breward, N., Cave, M., Lister, T.R., Ingham, T.R., Gowing, R., Carter, S., 2012. The advanced soil geochemical atlas of England and Wales. British Geological Survey.

Resongles, E., Casiot, C., Freydier, R., Dezileau, L., Viers, J., Elbaz-Poulichet, F., 2014. Persisting impact of historical mining activity to metal $(\mathrm{Pb}, \mathrm{Zn}, \mathrm{Cd}, \mathrm{Tl}, \mathrm{Hg})$ and metalloid (As, Sb) enrichment in sediments of the Gardon River, Southern France. Sci. Total Environ. 481, 509-521.

Rimondi, V., Gray, J.E., Costagliola, P., Vaselli, O., Lattanzi, P., 2012. Concentration, distribution, and translocation of mercury and methylmercury in mine-waste, sediment, soil, water, and fish collected near the Abbadia San Salvatore mercury mine, Monte Amiata district, Italy. Sci. Total Environ. 414, 318-327.

Ruiz, F., Borrego, J., González-Regalado, M.L., López González, N., Carro, B., Abad, M., 2008. Impact of millennial mining activities on sediments and microfauna of the Tinto River estuary (SW Spain). Mar. Pollut. Bull. 56 (7), 1258-1264.

Sahuquillo, A., López-Sánchez, J.F., Rubio, R., Rauret, G., Thomas, R.P., Davidson, C.M., Ure, A.M., 1999. Use of a certified reference material for extractable trace metals to assess sources of uncertainty in the BCR three-stage sequential extraction procedure. Anal. Chim. Acta 382 (3), 317-327.

Salminen, R., chief-ed., Batista, M.J., Bidovec, M., Demetriades, A., De Vivo, B., De Vos, W., Duris, M., Gilucis, A., Gregorauskiene, V., Halamic, J., Heitzmann, P., Lima, A., Jordan, G., Klaver, G., Klein, P., Lis, J., Locutura, J., Marsina, K., Mazreku, A., O'Connor, P.J., Olsson, S., Ottesen, R.T., Petersell, V., Plant, J.A., Reeder, S., Salpeteur, I., Sandström, H., Siewers, U., Steenfeldt, A., Tarvainen, T., 2005, FOREGS Geochemical Atlas of Europe, Part 1 - Background information, methodology and maps: Geological Survey of Finland, Espoo

Sherman, D.M., Randall, S.R., 2003. Surface complexation of arsenic(V) to iron(III) hydroxides: Structural mechanism from ab initio molecular geometries and EXAFS spectroscopy. Geochim. Cosmochim. Acta 67, 4223-4230.

Sin, S.N., Chua, H., Lo, W., Ng, L.M., 2001. Assessment of heavy metal cations in sediments of Shing Mun River, Hong Kong. Environ. Int. 26, 297-301.

Tang, W., Shan, B., Zhang, W., Zhang, H., Wang, L., Ding, Y., 2014. Heavy metal pollution characteristics of surface sediments in different aquatic ecosystems in eastern china: a comprehensive understanding. PLoS One 9 (9), e108996.

Tornero, V., Arias, A.M., Blasco, J., 2014. Trace element contamination in the Guadalquivir River Estuary ten years after the Aznalcóllar mine spill. Mar. Pollut. Bull. 86 (1), 349-360.

Varol, M., 2013. Dissolved heavy metal concentrations of the Kralkızı, Dicle and Batman dam reservoirs in the Tigris River basin, Turkey. Chemosphere 93 (6), 954-962.

Vrhovnik, P., Rogan Šmuc, N., Dolenec, T., Serafimovski, T., Dolenec, M., 2013. Impact of $\mathrm{Pb}-\mathrm{Zn}$ mining activity on surficial sediments of Lake Kalimanci (FYR Macedonia). Turk. J. Earth Sci. 22 (1), 996-1009.

Wang, Y., Yang, L., Kong, L., Liu, E., Wang, L., Zhu, J., 2015. Spatial distribution, ecological risk assessment and source identification for heavy metals in surface sediments from Dongping Lake, Shandong, East China. Catena 125, 200-205.

Wang, J., Liu, G., Liu, H., 2016. Metal distribution and bioavailability in surface sediments from the Huaihe River, Anhui, China. Environ. Monit. Assess. 188 (1), 1-13.

Wei, X., Han, L., Gao, B., Zhou, H., Lu, J., Wan, X., 2016. Distribution, bioavailability, and potential risk assessment of the metals in tributary sediments of Three Gorges Reservoir: the impact of water impoundment. Ecol. Indic. 61, 667-675.

Yang, Z., Wang, Y., Shen, Z., Niu, J., Tang, Z., 2009. Distribution and speciation of heavy metals in sediments from the mainstream, tributaries, and lakes of the Yangtze River catchment of Wuhan, China. J. Hazard. Mater. 166 (2), 1186-1194.

Yuan, X., Zhang, L., Li, J., Wang, C., Ji, J., 2014. Sediment properties and heavy metal pollution assessment in the river, estuary and lake environments of a fluvial plain, China. Catena 119, 52-60.

Zakir, H.M., Shikazono, N., 2011. Environmental mobility and geochemical partitioning of $\mathrm{Fe}, \mathrm{Mn}, \mathrm{Co}, \mathrm{Ni}$ and $\mathrm{Mo}$ in sediments of an urban river. J. Environ. Chem. Ecotoxicol. 3 (5), 116-126

Zhu, H.N., Yuan, X.Z., Zeng, G.M., Jiang, M., Liang, J., Zhang, C., Yin, J., Huang, H.J., Liu, Z.F., Jiang, H.W., 2012. Ecological risk assessment of heavy metals in sediments of Xiawan Port based on modified potential ecological risk index. Trans. Nonferrous Metals Soc. China 22 (6), 1470-1477. 